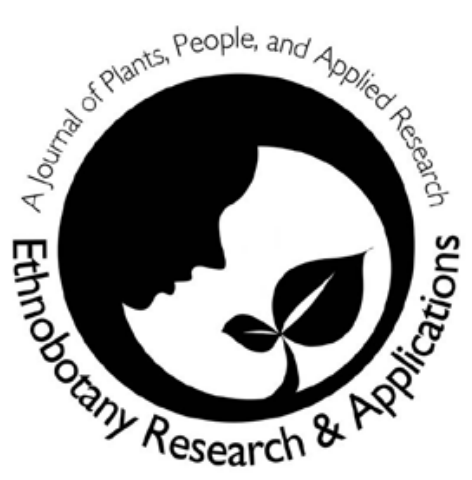

\title{
Medicinal Plants and Forest Transformations in Northwest Pakistan: A preliminary synthesis
}

\author{
Muhammad Adnan and Dirk Hölscher
}

\section{Research}

\begin{abstract}
In the Pakistani Himalaya, local people use medicinal plants for healthcare and income generation. Medicinal plants have historically been collected below the tree line from near natural old-growth forests. However, such forests have almost disappeared today. In addition to the few remaining degraded forest remnants, some areas have become subject to restorative land-use approaches including agroforestry, reforestation, and natural re-growth. We studied a number of such transformational forest areas with respect to the abundance of medicinal plants and their local market prices. Of the ten target species studied, Viola canescens Wall. was the most valuable with the highest density occurring under old-growth forest, whereas it was almost absent from heavily degraded forest. Curiously, in new forests, its density was nine times higher under natural re-growth forest plots than under reforestation or agroforestry plots. Over the past six years, Viola's market value has increased 2.6 times more than the consumer price index, and the rising market costs of ten study species are strongly related to their densities in old-growth forest $\left(r^{2}=0.6, p<001\right)$. We assume this is related to the decline of old-growth forests and the consequent effects on the supply and demand of medicinal plants. Moreover, our results indicate close similarity of medicinal plant flora between old-growth and natural re-growth forests $(0.56$ Jaccard index). In conclusion, forest restoration with an emphasis on natural re-growth is important to the recovery of medicinal plants in Northwest Pakistan. Awareness of this outcome among locals may help to promote acceptance of reforestation measures in the region.
\end{abstract}

\section{Introduction}

Medicinal plants are important non-timber forest products (NTFPs) whose decline has long been a matter of high concern due to their role in promoting human health and well-being (Arnold \& Pérez 2001). The international market for herbal products is estimated to be worth some US $\$ 83$ billion (Robinson \& Zhang 2011) and the World Health Organization estimates that $70-95 \%$ of people living in developing countries rely chiefly on medicinal plants for their primary healthcare needs (Robinson \& Zhang 2011). Ten thousand medicinal plants are currently threatened globally (Hamilton 2004), yet the supply of such NTFPs is essential to both conservation and human livelihoods (Ticktin 2004). Achieving the sustainable restoration of medicinal plant habitat will depend on the effective interlinking of ecological, socio-cultural, and economic factors (Ghimire et al. 2004).

Pakistan's forest area covers as little as $4.8 \%$ of the country's total area, yet the country is still subject to high levels of deforestation at $2.3 \%$ annually (FAO 2010). An estimated 6000 thousand higher plants are reported for Pakistan, of which $33 \%$ are NTFP species (Shinwari 2010). The availability of effective herbs coupled with the tra-

\section{Correspondence}

Muhammad Adnan, Department of Botany, Kohat University of Science and Technology, 26000 Kohat, Khyber Pakhtunkhwa, PAKISTAN. ghurzang@hotmail.com

Dirk Hölscher, Tropical Silviculture and Forest Ecology, Georg-August-Universität Göttingen, Büsgenweg 1, 37077 Göttingen, GERMANY.

Ethnobotany Research \& Applications 12:607-625 (2014)

Published: 26 November 2014 
ditional knowledge of pharmacology and relative lack of side effects make medicinal plant treatments more attractive than allopathic treatments. Indeed, around 600 $(10 \%)$ of all reported species are currently used as medicinal plants, 500 of which are commonly used in traditional healthcare practices while 350 are traded on national and international markets (Ahmad 2003), with the total annual export value reaching approximately US \$20 million (Shinwari 2010).

In spite of the economic value of such species and associated land-use, the forests of Northwest Pakistan continue to be subject to various types of anthropogenic disturbance, which have turned some near-natural old-growth forests into various types of degraded forests (WWF-P 2004). Most of the medicinal plant species occur as understory herbs, and deforestation, overgrazing, and overcollection have decimated several medicinal plant species that locals depend on for their livelihoods (Ahmad 2003).

It has been reported that if degraded forests are allowed to re-grow or are seeded, the probability of re-occurrence of understory species may increase (Barbier et al. 2008,
Parrotta et al. 1997). Forest restoration can accelerate forest succession on a previously degraded site by influencing light availability, understory microclimate, vegetation structural complexity, and development of humus layers during the early years of plantation growth (Parrotta et al. 1997, Yirdaw 2001). Lamb et al. (2005) revealed lower relative biodiversity among degraded forests subject to agricultural intensification and higher levels of biodiversity restoration under natural re-growth conditions than in areas reforested with fast-growing tree species. Such studies are scarce, particularly for the Himalayan forests of Pakistan. Thus, this study provides an opportunity to evaluate how forest degradation and subsequent forest restoration bring about changes in the abundance of medicinal plants. We tested Lamb et al.'s (2005) concept in the context of Northwest Pakistan, where our main emphasis was on the relationship between various types of forest restoration and the abundance of medicinal plants. Figure 1 presents a hypothetical relationship between declining medicinal plant abundance and canopy cover (i.e., forest degradation). As forests are restored, medicinal plant abundance can recover, however, the extent of recovery may depend on the type of forest restoration, i.e., whether

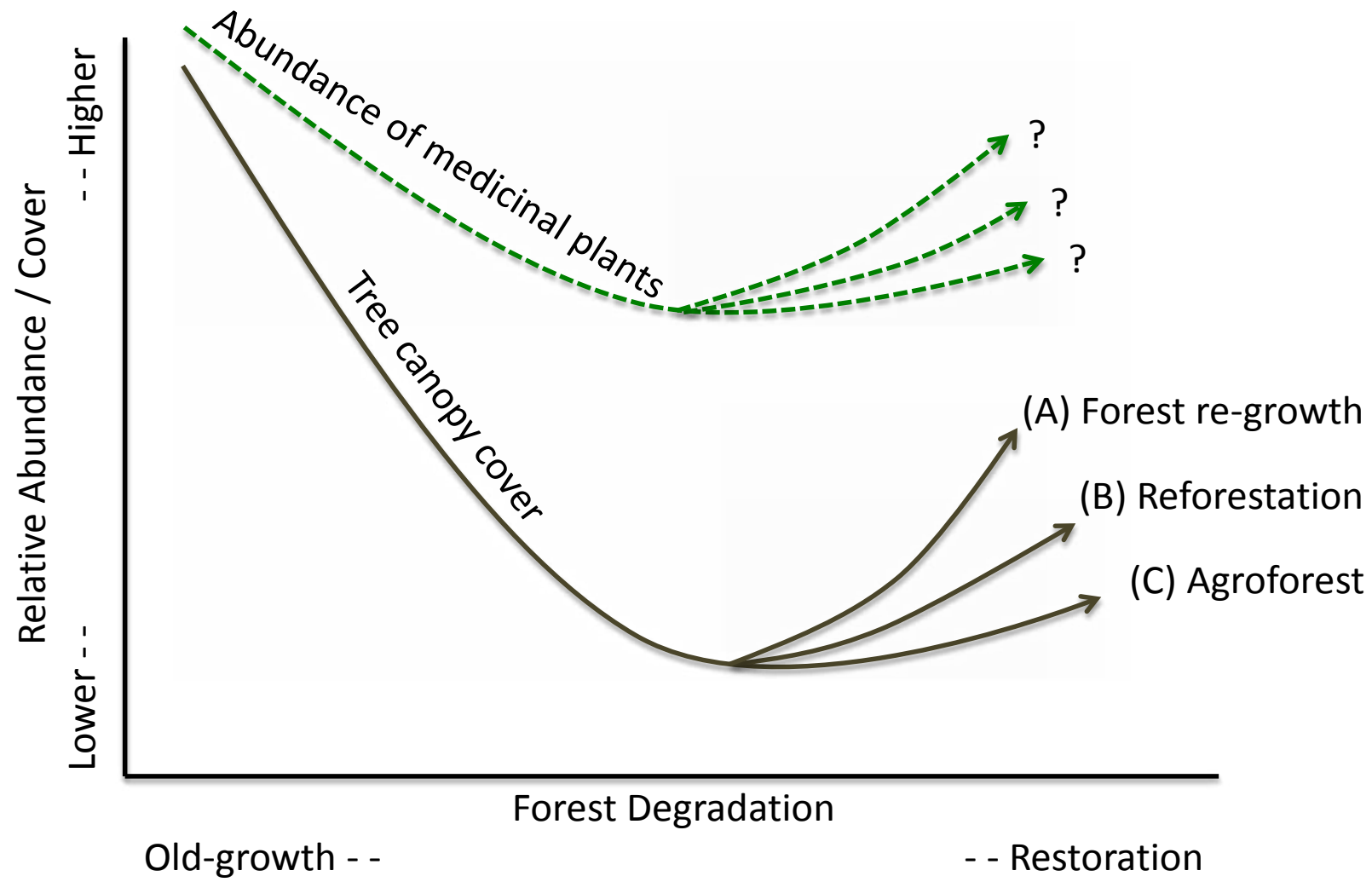

Figure 1. A hypothetical curve showing a strong affinity of medicinal herbs to old-growth forest. The line of medicinal plant abundance is speculative and indicates a decline as tree canopy cover decreases due to forest degradation. Tree canopy cover increases under forest restoration ( $A, B$, and $C$ ); however, change in the abundance of medicinal plants depends on the type of forest restoration. This concept is taken from Lamb et al. (2005), a study on biodiversity under various restored forest types following agricultural intensification. 


\section{Adnan \& Hölscher - Medicinal Plants and Forest Transformations in Northwest Pakistan: A preliminary synthesis}

it is natural re-growth forest, reforestation with fast-growing tree species, and/or agroforestry.

\section{Materials and Methods}

\section{Study area}

The present study was carried out in Ayubia National Park (ANP) and surrounding forest located in Northwest Pakistan. The study area is centered around $33^{\circ} 01^{\prime}$ to $34^{\circ} 38^{\prime}$ $\mathrm{N}$ and $73^{\circ} 20^{\prime}$ to $73^{\circ} 30^{\prime} \mathrm{E}$ and covered 8978 ha within an altitudinal range of 1220-2865 m (Figure 2A) (WWF-P 2004). The area has a mean annual precipitation of 1500 $\mathrm{mm}$ and mean annual temperature of $12^{\circ} \mathrm{C}$. Approximately 50,000 people live around the park and are heavily dependent on forest resources (WWF-P 2004). Abies pindrow (Royle ex D.Don) Royle and Pinus wallichiana A.B.Jacks. are the dominant tree species (Shafiq 2003).

\section{Forest-use types}

ANP forests are designated as "reserved" forests and "Guzara" forests. Reserved forests are defined as forests in which any human disturbance is prohibited unless permitted by the government. Guzara forests are private forests owned by the villagers to meet their domestic requirements for forest products (WWF-P 2004). Anthropogenic pressures such as heavy logging, overgrazing, agricultural expansion, and over-collection of NTFPs persist in the ANP and surrounding forests. Such pressures have transformed the natural old-growth forest into various types of degraded and restored forests. Grazing, fodder collection, and limited timber harvesting have transformed oldgrowth forests into derived woodland. Heavy clear-cutting for timber and wood-fuel have resulted in the transformation of some old-growth forests and derived woodland into forests (heavily) degraded by logging. More recently, forest restoration has taken place in the form of re-growth forest, reforestation, and agroforestry.

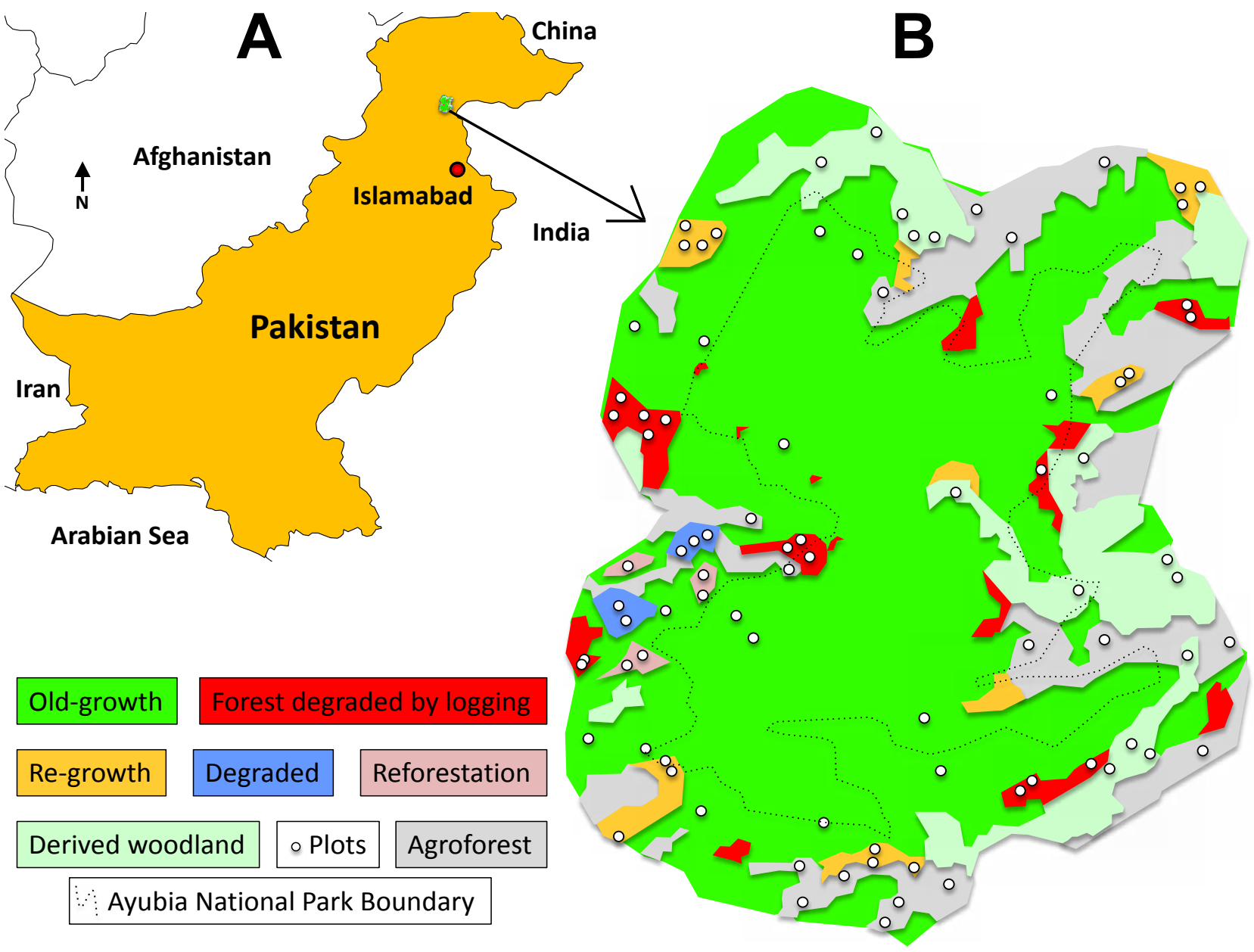

Figure 2. Study area in Northwest Pakistan with forest-use types, and plot design: (A) Pakistan and the location of the study region; (B) The study region showing the Ayubia National Park (ANP) boundary (inside line), its surrounding forests (outside boundary), and randomly selected study plots in all forest-use types (dots). 
In the study area, we classified seven forest-use types according to the nomenclature proposed by Putz and Redford (2010). These are:

1. Old-growth forest (Figure 3): forest with little or no human disturbance; can mainly be found in the ANP and in surrounding reserve forests; should consequently be afforded the highest level of protection from resource exploitation by the state forest department;

2. Derived woodland: forest under high grazing pressure where people frequently collect fodder and medicinal plants;

3. Forest degraded by logging: forest considerably affected by tree felling where many stumps can be found; collection of medicinal plants was a common practice in this forest-use type;

4. Degraded sites: former old-growth forest that have been deforested during the last three or four decades, leaving only a few $P$. wallichiana trees; provides open access to grazing animals and locals for fodder and medicinal plants collection;

5. Agroforest: areas of intense, long-term cultivation with fruit trees (peach, pears, etc.), a few native trees ( $P$. wallichiana, etc.), and some grass species (Sorghum);

6. Reforested sites: formerly degraded areas planted with four native tree species (Robinia pseudoacacia L., Aesculus indica (Wall. ex Cambess.) Hook., Populus ciliata Wall. ex Royle, and Salix tetrasperma Roxb.);

7. Re-growth forests (Figure 4): areas currently regenerating after heavy logging (20-50 years ago) with many trees of narrow diameter.

\section{Tree inventory and medicinal plant} assessment in forest-use types

For this study, we combined the data of three previously published articles along with some new data. The combination has revealed exclusively new trends and promoted a framework for future research. Fieldwork was carried out during two periods: July to October 2008 and June to September 2009. An approximate GIS-based map was developed that consisted of seven forest-use types (Figure $2 \mathrm{~B}$ ) identified through a reconnaissance survey. Five plots were randomly assigned to each of the degraded sites and reforestation sites (Adnan \& Hölscher 2010), while 15 study plots each were randomly assigned to oldgrowth forest, derived woodland, forest degraded by logging, agroforest, and re-growth forest (Adnan \& Hölscher 2011, 2012). Random numbers were generated and used for the $X$ and $Y$ axes using GIS and ILWIS software to identify coordinates for the center of each sample point (ITC 2007). Each plot consisted of a tree inventory plot of $20 \times 20 \mathrm{~m}\left(400 \mathrm{~m}^{2}\right)$ and a plot strip of $20 \times 2 \mathrm{~m}\left(40 \mathrm{~m}^{2}\right)$ within each inventory plot for the assessment of medicinal plants. Plots mainly had northern aspects and lay on inclines ranging from $2 \%$ to $35 \%$ within an altitudinal range of 2100-2400 masl. The distance of each plot from the closest human settlement ranged from 0.0 to $3.2 \mathrm{~km}$.
The tree inventory developed for each plot included tree canopy cover, tree basal area, species richness, stem density, and Shannon diversity index. Minimum size of 10 $\mathrm{cm} \mathrm{dbh}$ of trees was measured in all forest-use types. On the plot level basal area, species richness and stem density were assessed. Shannon-Wiener diversity index $\mathrm{H}^{\prime}$ (Magurran 2004) of trees was calculated for each inventory plot. Hemispherical photographs were taken vertically along the center of plot with a high resolution digital camera (Minolta Dimage Xt, Japan) using a $185^{\circ}$ fish-eye lens placed in a levelling device (Regent Instruments, Canada) on top of a tripod. Images were analyzed for tree canopy cover with CanEye 5.0 (INRA 2007).

Medicinal plant variables included density, species richness, and Shannon diversity index. The Jaccard abundance-based similarity index (Chao et al. 2005) was applied to quantify similarity of given forest-use type with old-growth forest on the basis of medicinal plant abundance. The Jaccard index compares compositional similarity of plants (abundance and richness) between two forest-use types at a range from 0 (no similarity) to 1 (total similarity). As the main objective of this study was to identify any new trends among the various types of forest restoration approaches following forest degradation, we only selected tree canopy cover and medicinal plant abundance from the collected data. Data on 10 medicinal plant species was used in this study, each of which has a high market value, is relatively easily identified in the field, and is of regional conservation concern. Index Kewensis (1997) was used to correct botanical names, family names, and publication authors of medicinal plants. Data on local medicinal plant names, other NTFP uses, medicinal uses, and part of plants used were recorded from available literature (Shafiq 2003, WWF-P 2004). The reproduction status and optimal light requirements of each plant were documented from available literature in accordance with Fern (1997). The market price of each medicinal plant species (Pakistani Rupees/kg of plant material used) in the years 2006 and 2012 were recorded from the local market at Abbottabad city and converted into US dollars (USD). These prices were collected from the main vendor in city. The vendor gave his consent for the publication of this data. This vendor buys medicinal plants from the majority of local collectors and other small vendors in the region. Hence, the prices were more reliable compared to other vendors. These prices are average prices of four months (June-September) of a year, during which local people collect medicinal plants from the forests. In order to ascertain the price increase of each plant over the Consumer Price Index (CPI) from 2006 to 2012, we adjusted for inflation between the two years (GoP 2013).

\section{Statistical analysis}

A Kruskal-Wallis test was applied to test for differences in the mean values of medicinal plant variables between each forest-use type. It was also applied to test the difference in the mean Jaccard abundance based similarity in- 
Northwest Pakistan: A preliminary synthesis

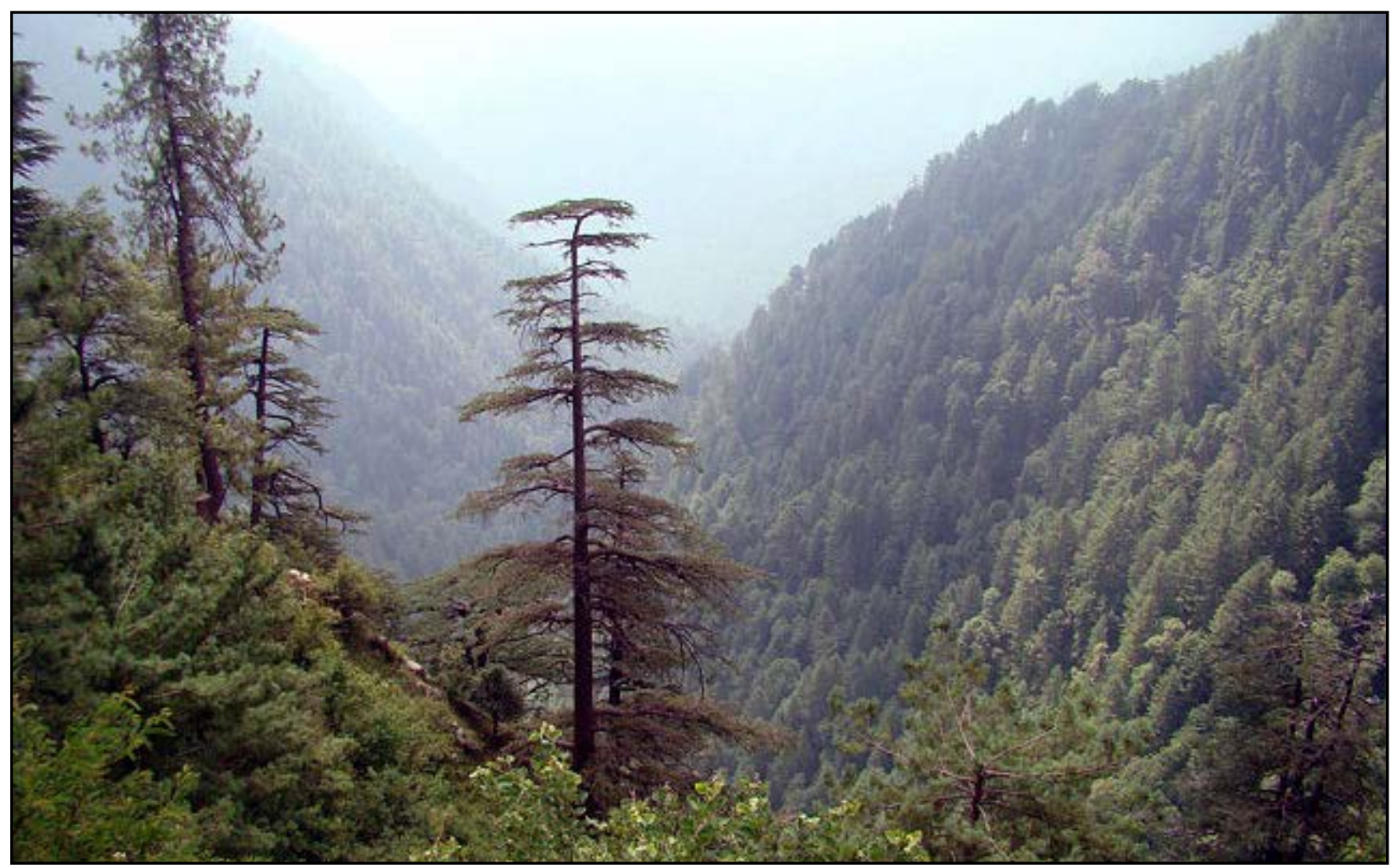

Figure 3. Old-growth forest in Northwest Pakistan

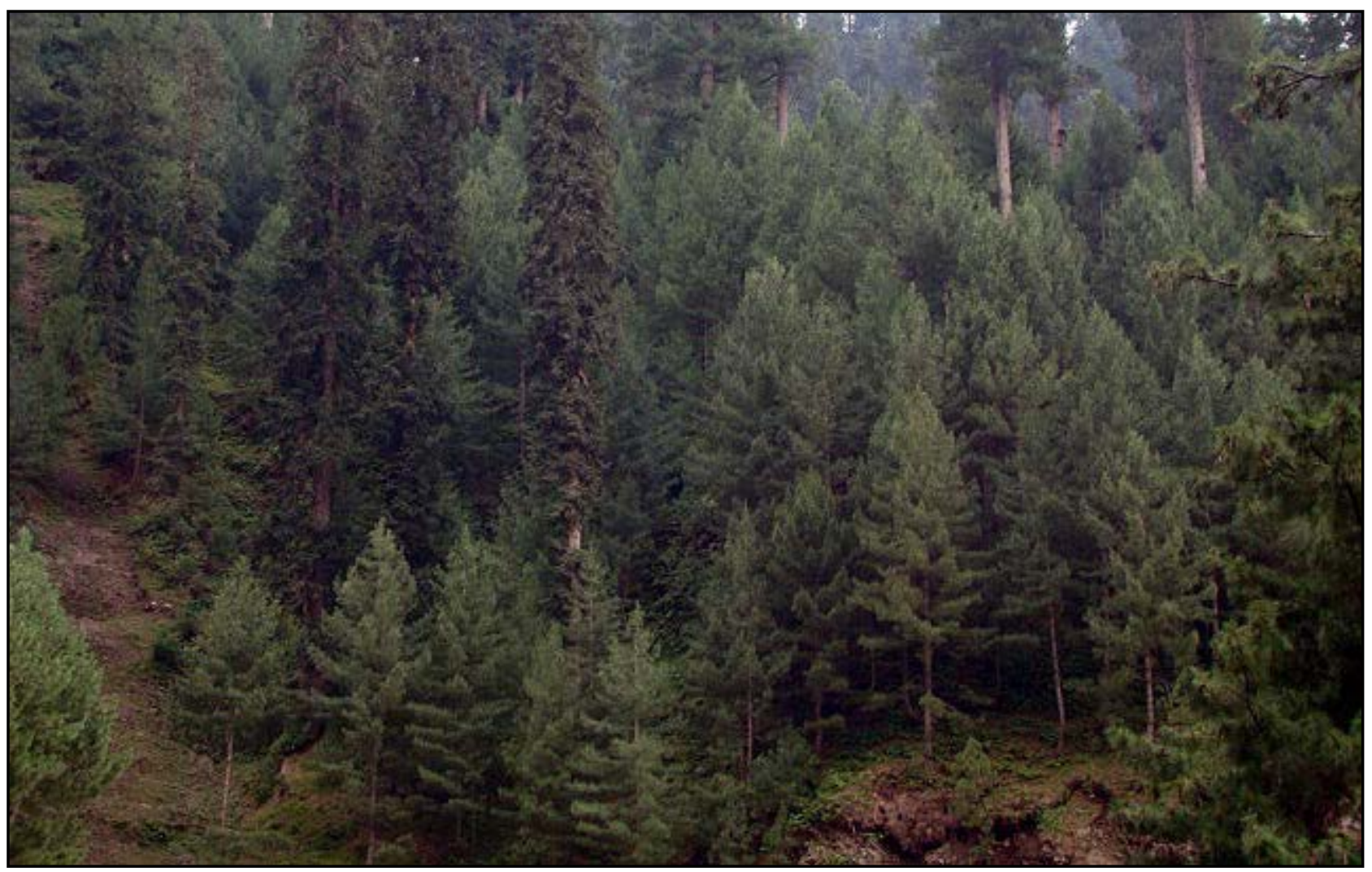

Figure 4. Re-growth forest in Northwest Pakistan 


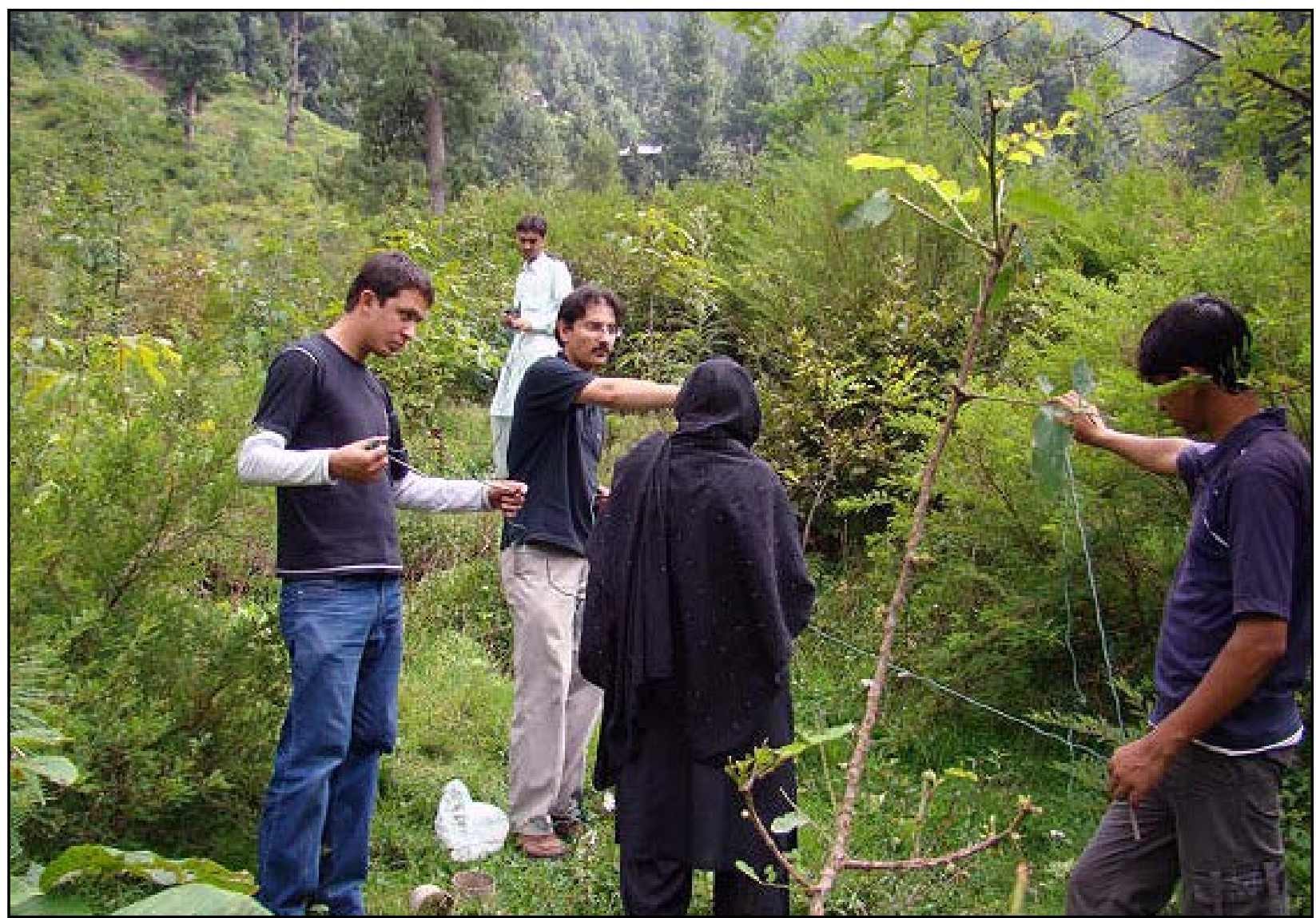

Figure 5. Plot data collection in Northwest Pakistan.

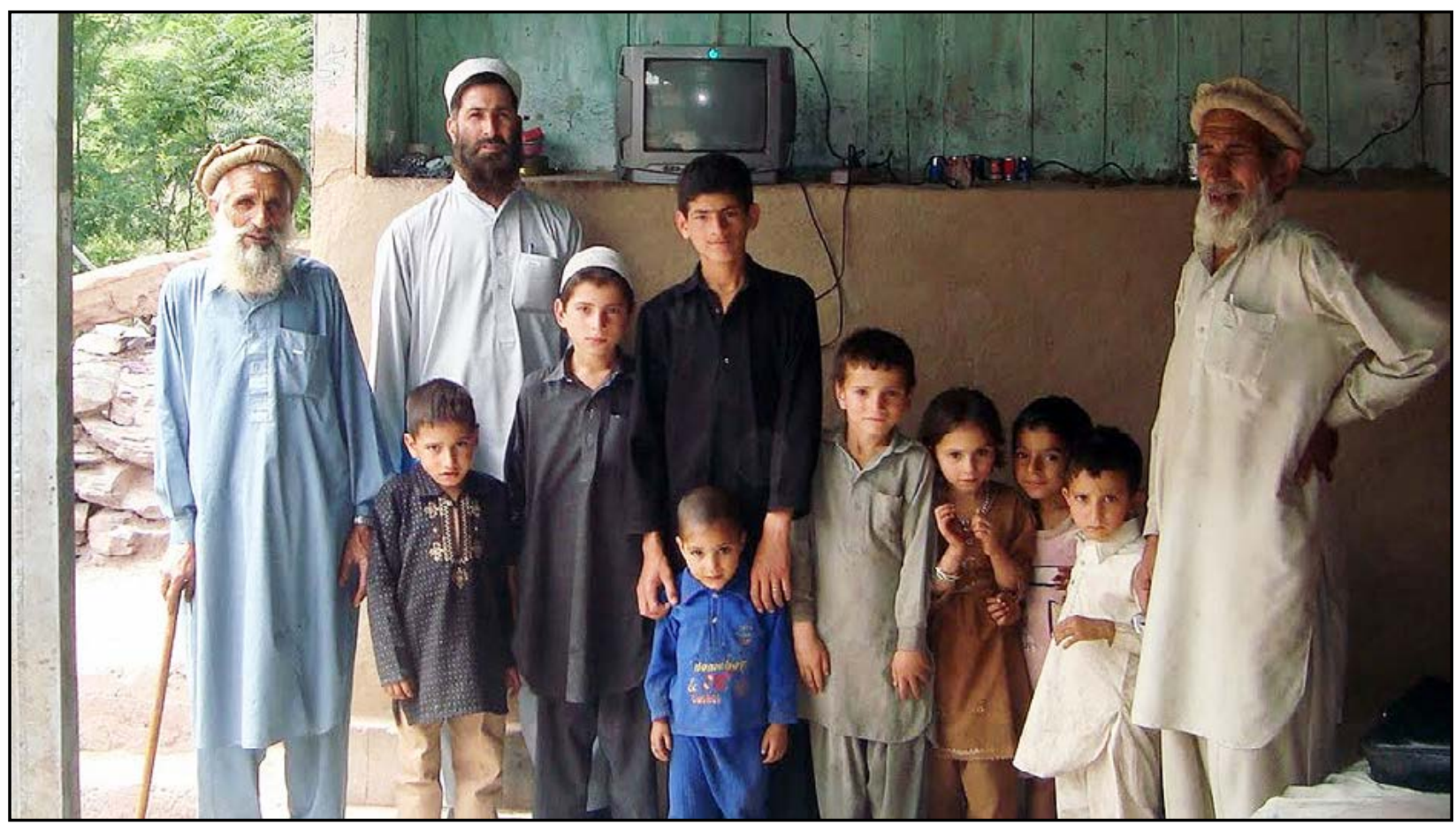

Figure 6. Typical family in Northwest Pakistan. 


\section{Adnan \& Hölscher - Medicinal Plants and Forest Transformations in Northwest Pakistan: A preliminary synthesis}

dex values between the six forest-use types to investigate their affinities with old-growth forest for medicinal plants. Spearman correlation was applied between the densities of the ten medicinal plant species and their associated price increases over CPI in old-growth forest. Kruskal-Wallis testing was performed in SPSS (version 16.0) (SPSS Inc. 2007).
Results

\section{Ethnomedicinal uses and market value}

Table 1 presents a comprehensive list of all the study species including their respective light requirements, uses, and market value. All 10 species were used for multiple medicinal and other purposes. Light requirements for species such as Valeriana jatamansi Jones (Figure 7) and Vi-

Table 1. Non-timber forest products (NTFP), including medicinal plants, their characteristics, and market prices in 2006 and 2012 recorded at the local level in Northwest Pakistan. FC = factor of increase over Consumer Price Index (2006 and 2012). Data on medicinal plant light requirements and uses were collected from available literature (Fern 1997, Shafiq 2003, WWF-P 2004): DS - Deep shade; PS - Partial shade, NS - No shade.

\begin{tabular}{|c|c|c|c|c|c|c|c|c|c|c|c|c|c|c|c|c|}
\hline \multicolumn{14}{|c|}{ Botanical species (Family) / Vernacular } & \multirow{3}{*}{\multicolumn{3}{|c|}{$\begin{array}{l}\text { Market Price } \\
\text { (US dollars- } \\
\text { kg-1 part use) }\end{array}$}} \\
\hline \multirow[b]{3}{*}{$\begin{array}{l}\text { Light } \\
\text { requirements }\end{array}$} & \multicolumn{13}{|c|}{ Uses } & & & \\
\hline & \multicolumn{6}{|c|}{ Parts } & \multicolumn{6}{|c|}{ NTFP } & \multirow[b]{2}{*}{ Medicinal } & & & \\
\hline & 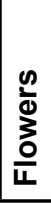 & 는 & 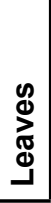 & $\begin{array}{l}0 \\
\stackrel{0}{0} \\
\stackrel{1}{\simeq}\end{array}$ & 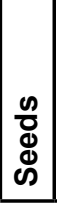 & $\begin{array}{l}\frac{\pi}{\frac{1}{0}} \\
\frac{0}{0} \\
\frac{0}{0} \\
\frac{c}{3} \\
\end{array}$ & 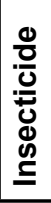 & \begin{tabular}{|l} 
\\
흥 \\
음 \\
\end{tabular} & 는 & 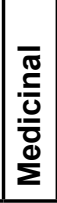 & 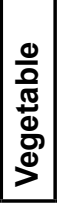 & 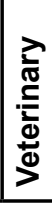 & & ஜ̊ & $\stackrel{N}{\grave{N}}$ & FC \\
\hline \multicolumn{17}{|c|}{ Bergenia ciliata Sternb. (Saxifragaceae) / Zakhm-e-hayat } \\
\hline DS-PS & & & $\mathrm{X}$ & $\mathrm{X}$ & & & & $\mathrm{x}$ & & $\mathrm{x}$ & & $\mathrm{X}$ & $\begin{array}{l}\text { Intestinal, stomach, fever, } \\
\text { chest, tonic, anti-cancer }\end{array}$ & 0.8 & 2.6 & 1.6 \\
\hline \multicolumn{17}{|c|}{ Galium aparine L. (Rubiaceae) / Kochan } \\
\hline PS-NS & & & & & & $\mathrm{X}$ & & $\mathrm{X}$ & & $\mathrm{X}$ & & $\mathrm{X}$ & $\begin{array}{l}\text { Liver and spleen, heart and } \\
\text { blood pressure, anti-cancer }\end{array}$ & 0.4 & 1.2 & 1.5 \\
\hline \multicolumn{17}{|c|}{ Geranium wallichianum D.Don ex Sweet (Geraniaceae) / Rattan jot } \\
\hline PS-NS & & & $\mathrm{X}$ & $\mathrm{X}$ & & & & $x$ & & $\mathrm{x}$ & & $\mathrm{X}$ & $\begin{array}{l}\text { Teeth, liver/spleen, diabetes, } \\
\text { gynecological disorders }\end{array}$ & 1.3 & 3.0 & 1.2 \\
\hline \multicolumn{17}{|c|}{ Paeonia emodi Wall. ex Royle (Paeoniaceae) / Ud-e-Saleeb } \\
\hline PS-NS & $\mathrm{X}$ & & & $\mathrm{X}$ & $\mathrm{X}$ & & & $\mathrm{X}$ & & $\mathrm{X}$ & $\mathrm{X}$ & & Headache, pain killer & 0.5 & 2.1 & 2.1 \\
\hline \multicolumn{17}{|c|}{ Persicaria amplexicaulis (D.Don) Ronse Decr. (Polygonaceae) / Anjabar } \\
\hline PS & & & $\mathrm{X}$ & $\mathrm{X}$ & & & & $\mathrm{X}$ & & $\mathrm{X}$ & & $\mathrm{X}$ & $\begin{array}{l}\text { Muscular, ear, nose \& throat, } \\
\text { gynecological disorders }\end{array}$ & 0.2 & 0.6 & 1.5 \\
\hline \multicolumn{17}{|c|}{ Plantago lanceolata L. (Plantaginaceae) / Ispaghol } \\
\hline NS & & & & & & $\mathrm{X}$ & & & & $\mathrm{X}$ & & & Stomach, teeth & 0.5 & 1.2 & 1.2 \\
\hline \multicolumn{17}{|c|}{ Sinopodophyllum hexandrum (Royle) T.S.Ying (Berberidaceae) / Ban kakri } \\
\hline DS-PS & & $\mathrm{x}$ & & $\mathrm{x}$ & $\mathrm{X}$ & & & & $X$ & $\mathrm{X}$ & & & $\begin{array}{l}\text { Intestinal, stomach, tonic, } \\
\text { liver and spleen, sexual }\end{array}$ & 1.7 & 5.2 & 1.5 \\
\hline \multicolumn{17}{|c|}{ Swertia chirata Buch.-Ham. ex Wall. (Gentianaceae) / Chirata } \\
\hline PS & & & & & & $\mathrm{X}$ & & & & $\mathrm{X}$ & & $\mathrm{x}$ & Fever, chest & 0.9 & 1.9 & 1.1 \\
\hline \multicolumn{17}{|c|}{ Valeriana jatamansi Jones (Caprifoliaceae) / Mushk-e-bala } \\
\hline DS-PS & & & $\mathrm{X}$ & $\mathrm{X}$ & & & $x$ & $\mathrm{x}$ & & $x$ & & & $\begin{array}{l}\text { Intestinal, stomach, } \\
\text { chest, urinary, tonic }\end{array}$ & 0.9 & 4.6 & 2.6 \\
\hline \multicolumn{17}{|c|}{ Viola canescens Wall. (Violaceae) / Banaf sha } \\
\hline DS-PS & & & & & & $X$ & & $\mathrm{X}$ & & $x$ & $x$ & & $\begin{array}{l}\text { Intestinal, stomach, fever, } \\
\text { chest, skin, urinary }\end{array}$ & 2.4 & 12.4 & 2.6 \\
\hline
\end{tabular}




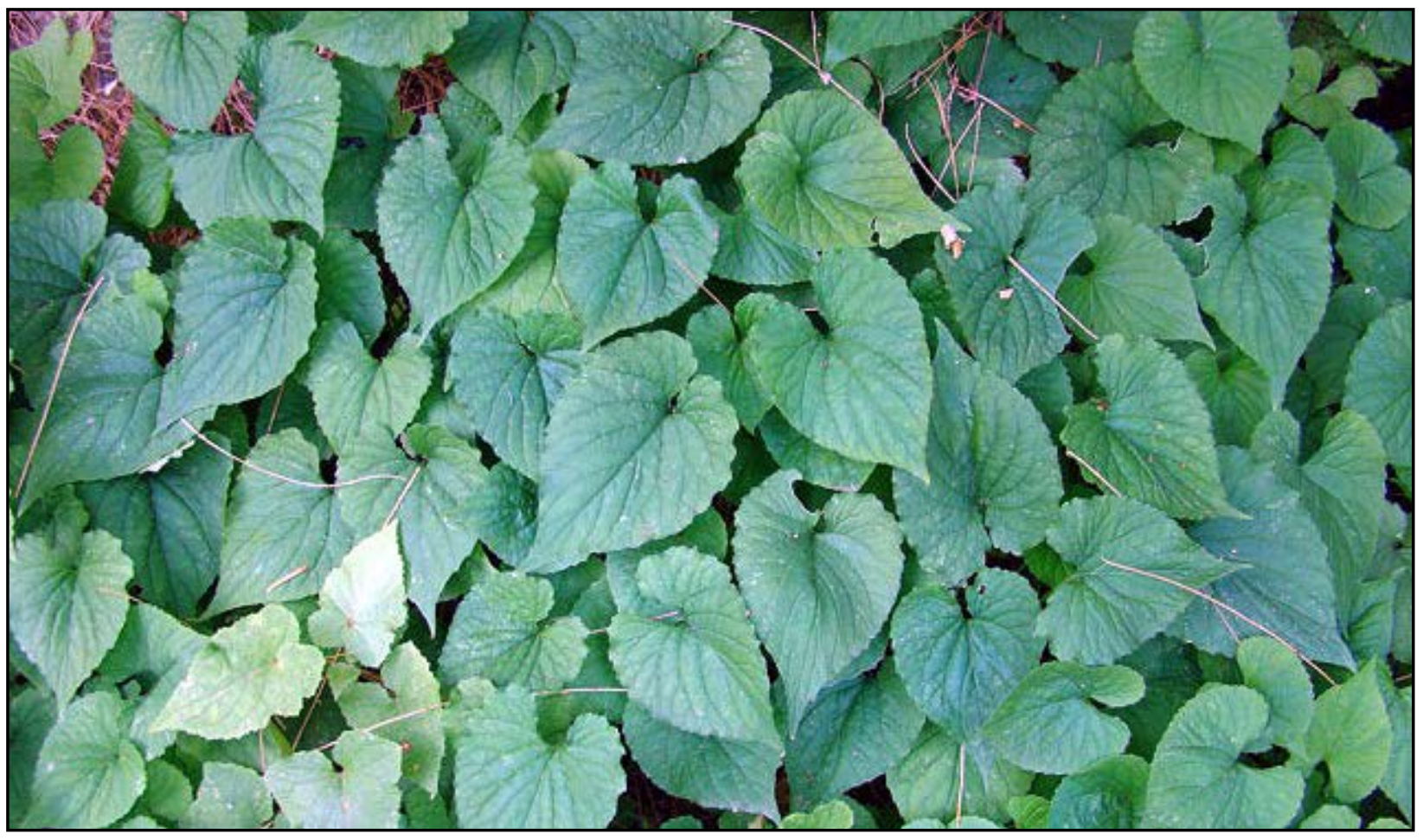

Figure 7. Valeriana jatamansi Jones (Caprifoliaceae) / Mushk-e-bala in Northwest Pakistan.

Table 2. Variation in tree and stand structural characteristics and medicinal plants among seven forest-use types in Northwest Pakistan showing mean and standard error ( $\mathrm{n} / \mathrm{a}=$ data not available; $\mathrm{n} / \mathrm{s}$ = not significant).

\begin{tabular}{|c|c|c|c|c|c|c|c|c|}
\hline \multirow{3}{*}{$\begin{array}{l}\text { Forest structure } \\
\text { and composition }\end{array}$} & \multicolumn{7}{|l|}{ Mean SE } & \multirow[b]{2}{*}{ 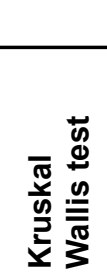 } \\
\hline & $\begin{array}{l}\text { 둔 } \\
30 \\
\text { 년 } \\
\frac{1}{9} \\
\frac{1}{0} \stackrel{0}{0}\end{array}$ & 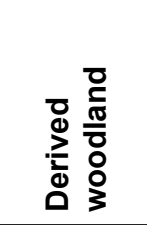 & 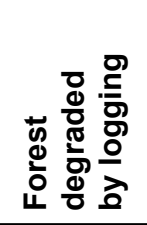 & 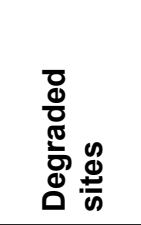 & $\begin{array}{l}\text { ஸे } \\
\frac{0}{0} \\
\frac{0}{0} \\
\frac{0}{4}\end{array}$ & 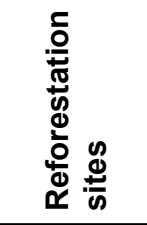 & 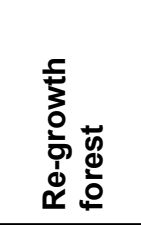 & \\
\hline & $(n=15)$ & $(n=15)$ & $(n=15)$ & $(n=5)$ & $(n=15)$ & $(n=5)$ & $(n=15)$ & \\
\hline $\begin{array}{l}\text { Total number of } \\
\text { tree species }\end{array}$ & 15 & 7 & 6 & 1 & 14 & 5 & & 12 \\
\hline 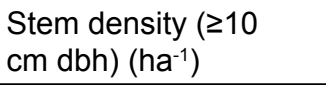 & $610 \pm 34$ & $305 \pm 52$ & $183 \pm 29$ & $50 \pm 11$ & $155 \pm 16$ & $630 \pm 75$ & $750 \pm 53$ & $P<0.01$ \\
\hline Basal area $\left(\mathrm{m} 2 \mathrm{ha}^{-1}\right)$ & $48 \pm 2$ & $15 \pm 2$ & $12 \pm 1$ & $3.0 \pm 0.1$ & $6.0 \pm 1$ & $8.0 \pm 0.1$ & $20 \pm 1$ & $P<0.01$ \\
\hline Tree canopy cover (\%) & $76 \pm 4$ & $56 \pm 4$ & $46 \pm 3$ & $4.0 \pm 3.5$ & $33 \pm 2$ & $36 \pm 9$ & $56 \pm 4$ & $P<0.01$ \\
\hline Shannon index, trees & $\begin{array}{r}0.94 \\
\pm 0.1 \\
\end{array}$ & $\begin{array}{r}0.62 \\
\pm 0.1 \\
\end{array}$ & $\begin{array}{r}0.49 \\
\pm 0.1 \\
\end{array}$ & 0 & $\begin{array}{r}0.76 \\
\pm 0.1 \\
\end{array}$ & $1.2 \pm 0.1$ & $\begin{array}{r}0.74 \\
\pm 0.1 \\
\end{array}$ & $P<0.05$ \\
\hline $\begin{array}{l}\text { Total number of } \\
\text { medicinal plants }\end{array}$ & 55 & $\mathrm{n} / \mathrm{a}$ & 40 & $\mathrm{n} / \mathrm{a}$ & $\mathrm{n} / \mathrm{a}$ & $\mathrm{n} / \mathrm{a}$ & 49 & \\
\hline \multicolumn{9}{|c|}{ Ten selected medicinal plants } \\
\hline Number of species & 10 & 8 & 7 & 7 & 5 & 10 & & 10 \\
\hline $\begin{array}{l}\text { Density as a } \\
\text { whole }\left(\mathrm{m}^{-2}\right)\end{array}$ & $\begin{array}{r}13.7 \\
\pm 1.73 \\
\end{array}$ & $5.6 \pm 0.9$ & $4.2 \pm 0.9$ & $1.3 \pm 0.4$ & $1.9 \pm 0.4$ & $9.8 \pm 4.4$ & $\begin{array}{r}10.4 \\
\pm 2.1 \\
\end{array}$ & $P<0.01$ \\
\hline Shannon evenness & $\begin{array}{c}0.77 \\
\pm 0.01\end{array}$ & $\begin{array}{c}0.74 \\
\pm 0.04\end{array}$ & $\begin{array}{c}0.67 \\
\pm 0.09\end{array}$ & $\begin{array}{c}0.56 \\
\pm 0.03\end{array}$ & $\begin{array}{c}0.62 \\
\pm 0.08\end{array}$ & $\begin{array}{r}0.78 \\
\pm 0.2\end{array}$ & $\begin{array}{c}0.79 \\
\pm 0.03\end{array}$ & $\mathrm{n} / \mathrm{s}$ \\
\hline
\end{tabular}




\section{Adnan \& Hölscher - Medicinal Plants and Forest Transformations in Northwest Pakistan: A preliminary synthesis}

ola canescens Wall. are deep to partial shade conditions. Both species are used for treating intestinal and chest related diseases. Species such as Gallium aparine L., Geranium wallichianum D.Don ex Sweet, and Paeonia emodi Wall. ex Royle are adapted to conditions from partial shade to no shade. These species are used locally for various diseases such as teeth, liver, and spleen problems as well as gynecological problems. Plantago lanceolata $\mathrm{L}$. is the only species adapted to non-shaded conditions and is extensively used for stomach disorders at the local level. The highest market price was recorded in the year 2012 at 12.40 USD kg-1 for the locally valuable $V$. canescens, which was 2.6 times higher than its inflation-adjusted price between 2006 and 2012. Similarly, the 2012 price of $V$. jatamansi (4.6 USD $\mathrm{kg}^{-1}$ ) was also observed to be 2.6 times higher than its inflation adjusted price (Table 1).

\section{Tree canopy cover and abundance of medicinal plants}

Mean tree canopy cover of old-growth forest (76\%) was highest across the forest-use types. Canopy cover decreased with forest degradation as observed for derived woodland (56\%), forest degraded by logging (46\%), and degraded sites (4\%). However, canopy cover increased with agroforest (33\%), reforested sites (36\%), and regrowth forest (56\%) (Table 2).

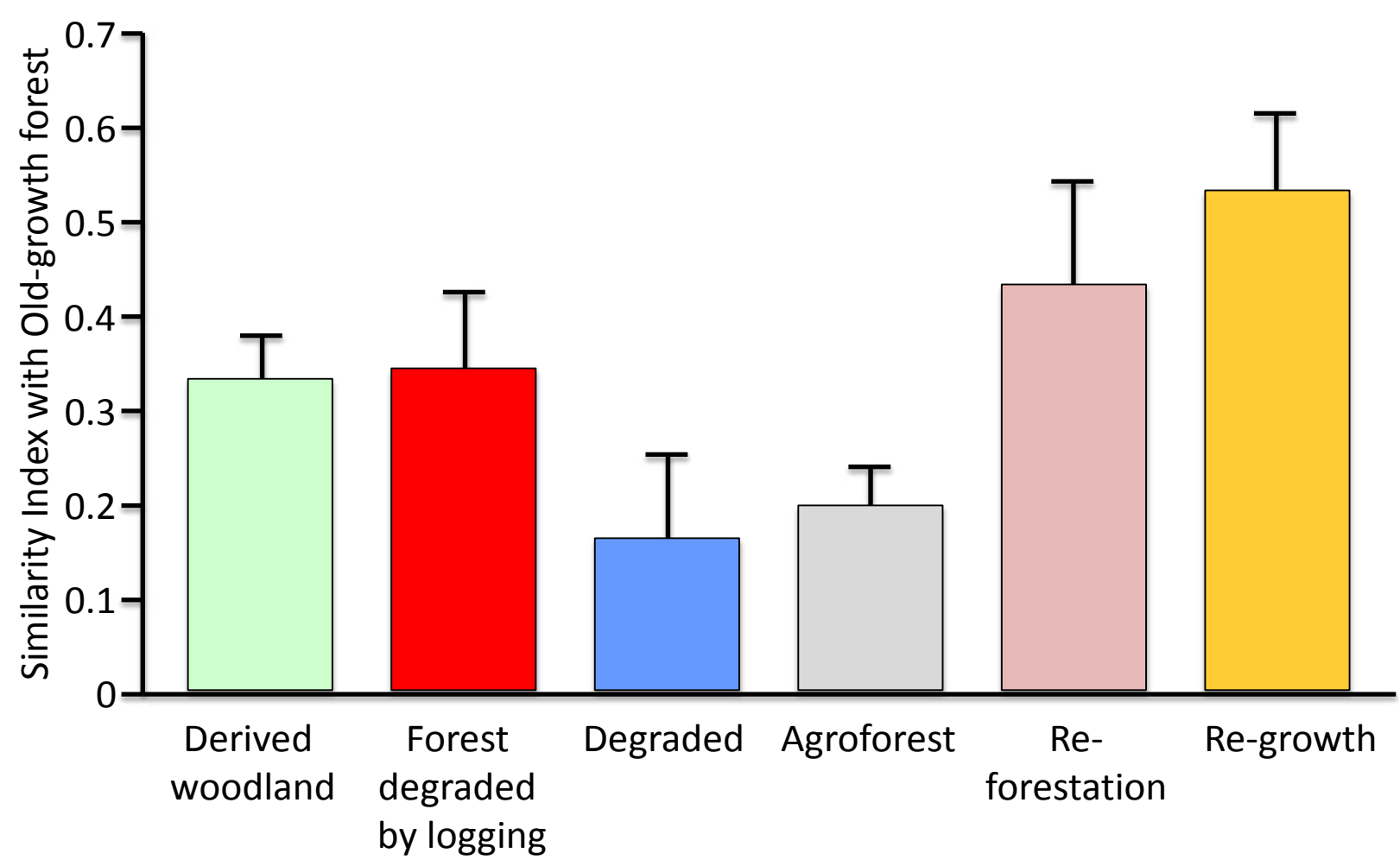

Old-growth forest plots had the highest mean density of all medicinal plants among forest-use types at $13.7 \mathrm{~m}^{-2}$. Lower mean density values were observed for all medicinal plant species in each of the degraded forest types (derived woodland $=5.6 \mathrm{~m}^{-2}$; forest degraded by logging = $4.2 \mathrm{~m}^{-2}$; degraded sites $=1.3 \mathrm{~m}^{-2}$ ). However, higher mean density values of all medicinal plants were observed in the restored forest types (agroforest $=1.9 \mathrm{~m}^{-2}$; reforestation sites $=9.8 \mathrm{~m}^{-2}$; re-growth forest $\left.=10.4 \mathrm{~m}^{-2}\right)($ Table 2$)$. For medicinal plant abundance, a significantly higher Jaccard similarity index with old-growth forest was recorded for re-growth forest $(0.56 \pm 0.06)$, followed by that derived for reforestation sites $(0.44 \pm 0.11)$. Agroforests $(0.19 \pm 0.05)$ in comparison to degraded sites $(0.17 \pm 0.09)$ showed a little higher similarity to old-growth forest (Figure 8).

Most of the medicinal plant species had higher densities in old-growth forest than in any other forest-use type. The density of species such as $V$. canescens was highest under old-growth forest $\left(4.3 \mathrm{~m}^{-2}\right)$ and lowest in degraded forests $\left(1.0 \mathrm{~m}^{-2}, 0.1 \mathrm{~m}^{-2}, 0.02 \mathrm{~m}^{-2}\right)$ (Figure 9J). In restored forests, the density of $V$. canescens was higher under regrowth forest $\left(1.8 \mathrm{~m}^{-2}\right)$ compared to reforestation sites $(0.2$ $\mathrm{m}^{-2}$ ) and agroforest $\left(0.2 \mathrm{~m}^{-2}\right)$. Similar trends under restored forests were observed for Bergenia ciliata Sternb. (Figure 9A) and $V$. jatamansi (Figure 9l). In contrast, the density of $P$. lanceolata was lowest under old-growth forest $(0.1$

Figure 8. Similarity between forest-use types and old-growth forest in Northwest Pakistan for 10 medicinal plant species (Jaccard abundance based similarity index after Chao et al. (2005)). Mean and standard error; $n=5$ for degraded and reforestation sites, while $n=15$ for the other forest-use types (Kruskal-Wallis test: $p<0.01$ ). 

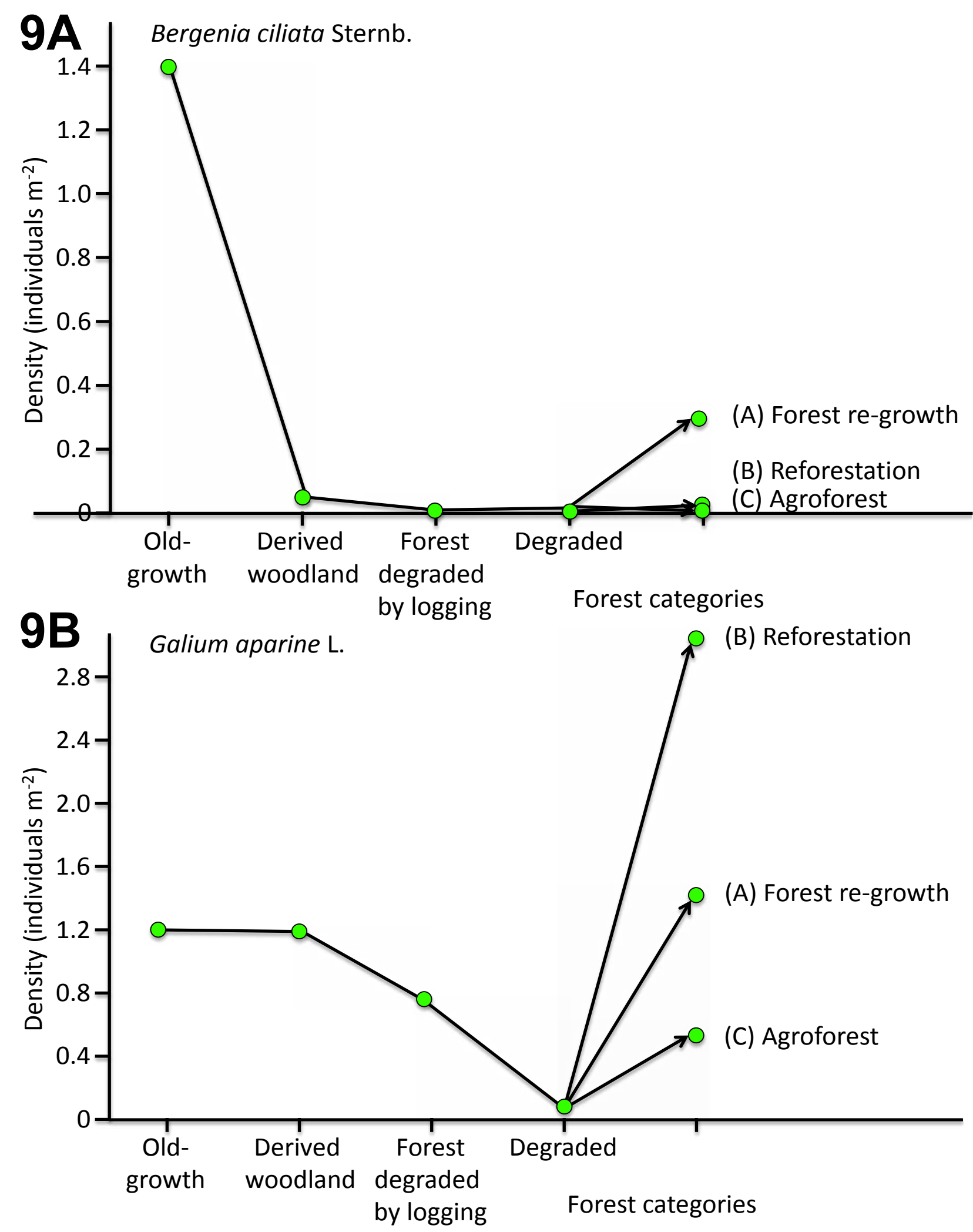

Figure 9. Changes in the abundance of individual medicinal plant species in relation to changes in tree canopy cover in Northwest Pakistan. Trend A represents natural re-growth of native tree species; Trend B represents reforestation sites of planted fast-growing tree species; Trend $C$ indicates degraded sites restored by agroforestry $(n=5$ for degraded and reforestation sites; $n=15$ for the other forest-use types). 

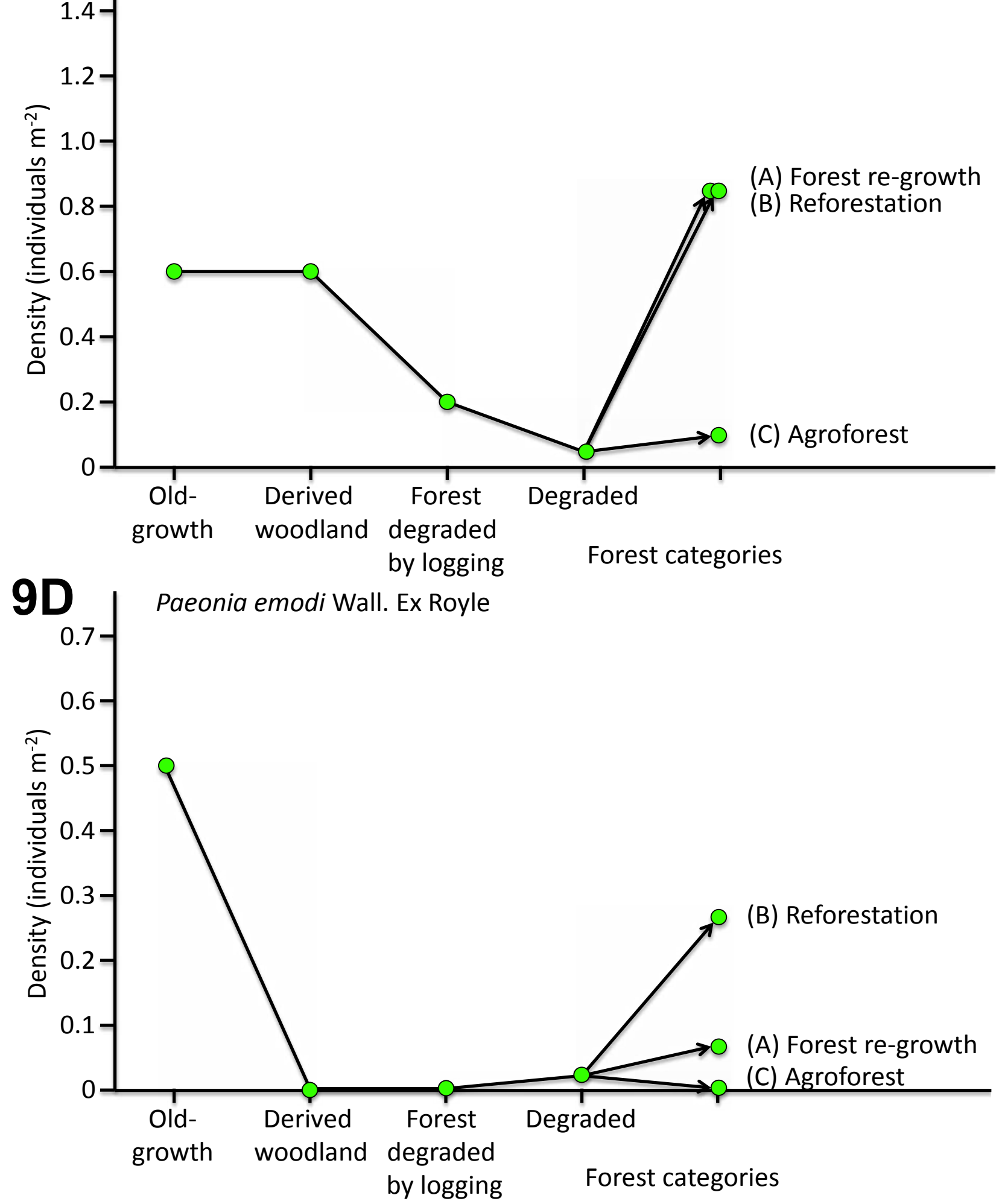
9E 1 Persicaria amplicaulis (D.Don) Ronse Decr.
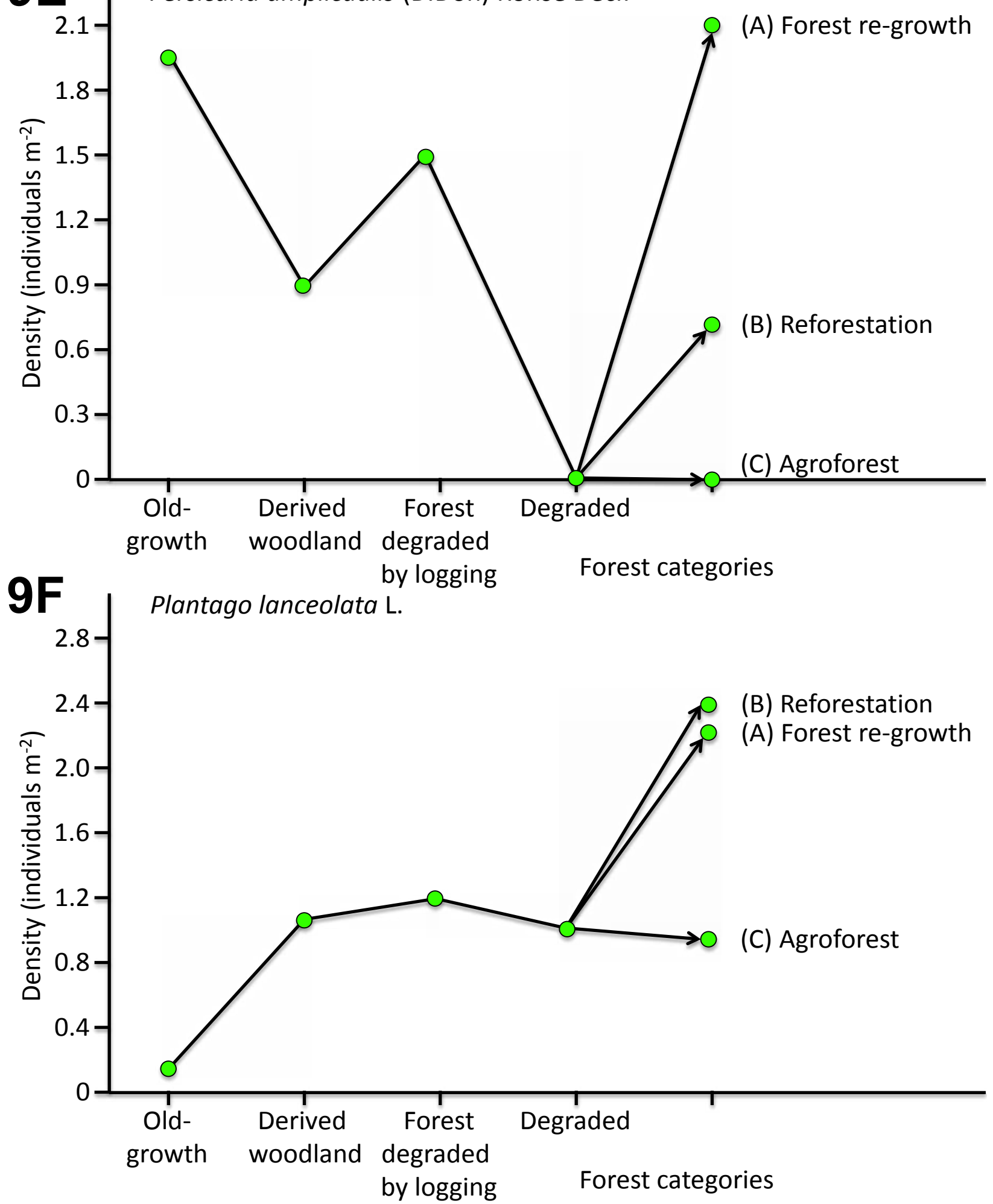

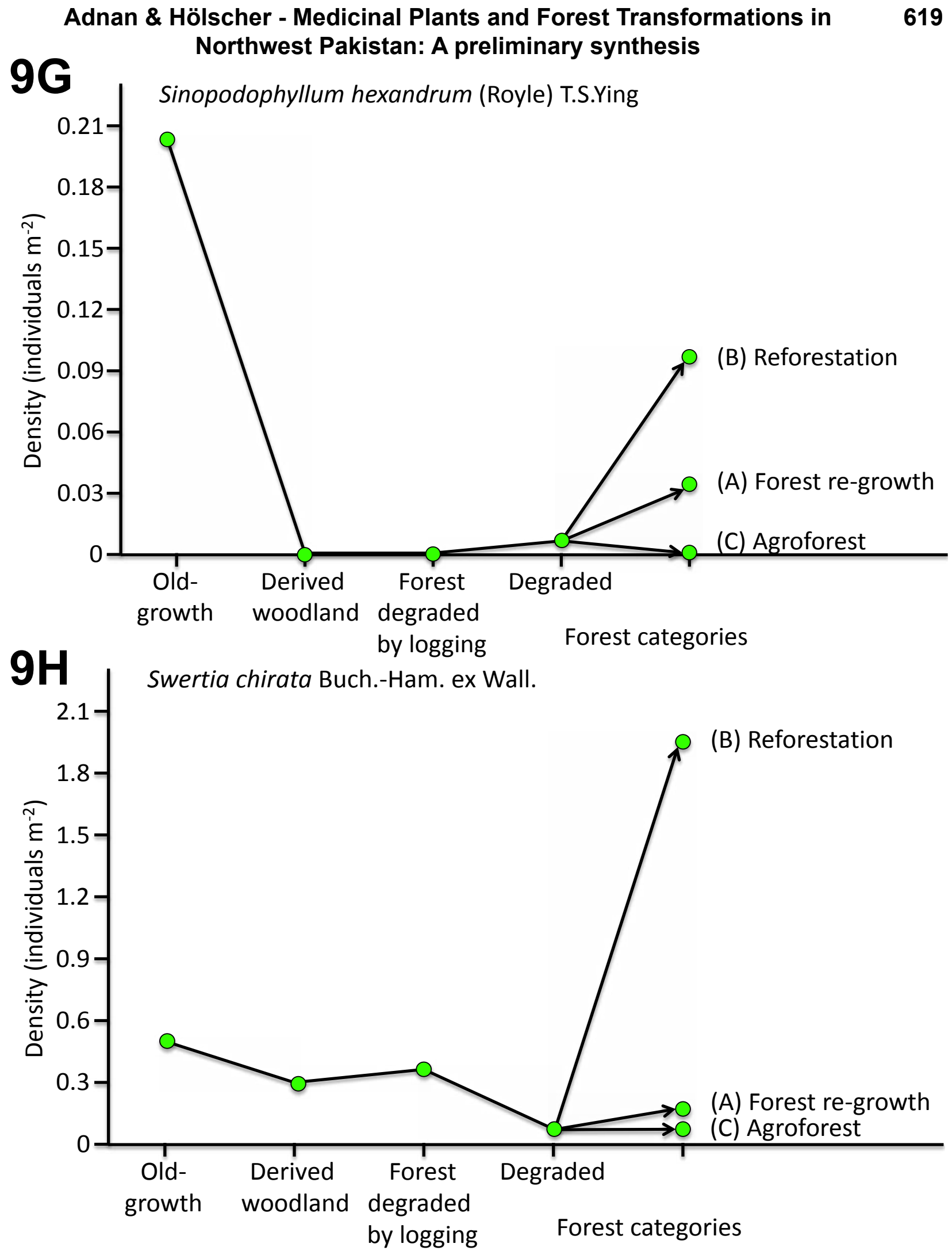

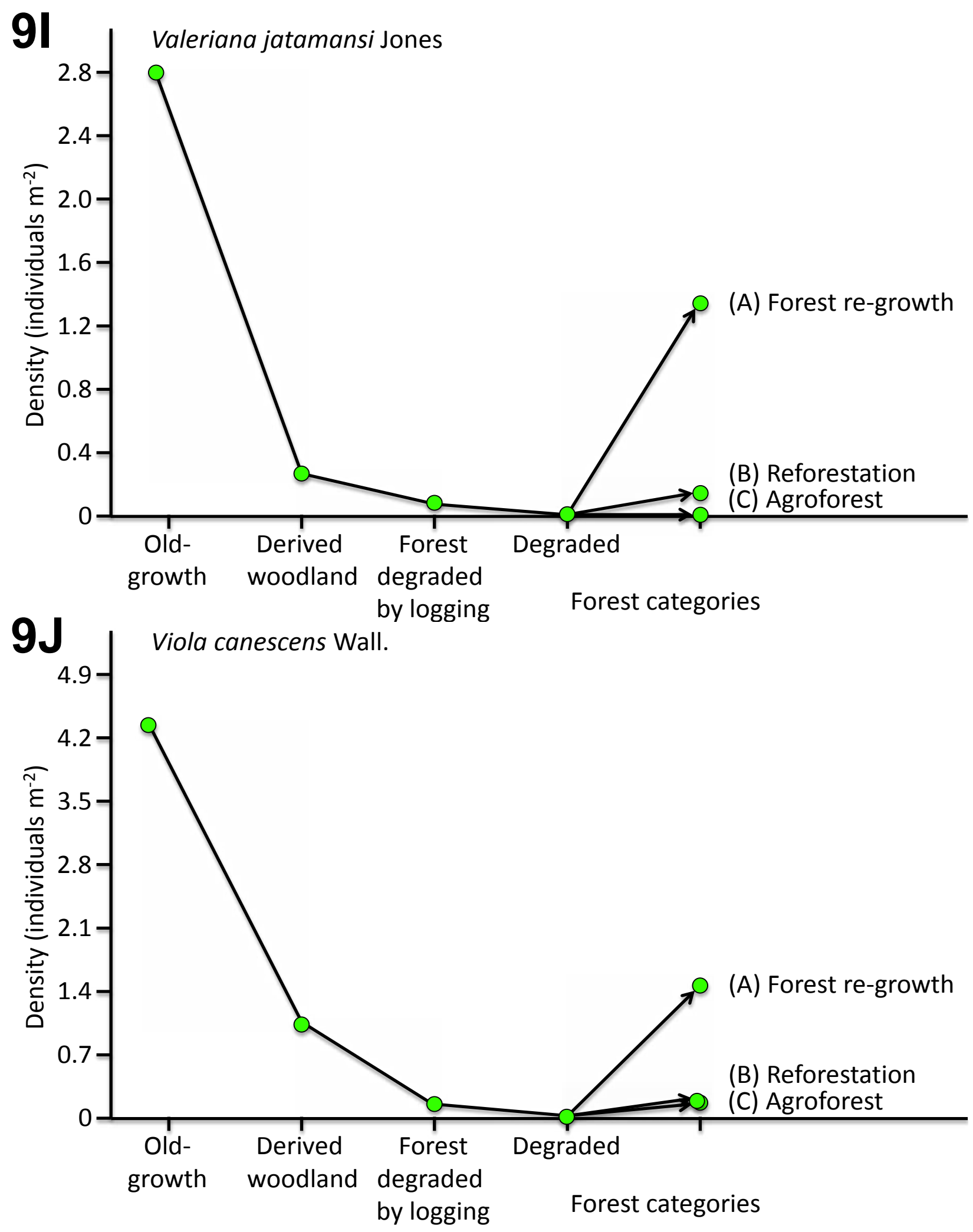


\section{Adnan \& Hölscher - Medicinal Plants and Forest Transformations in Northwest Pakistan: A preliminary synthesis}

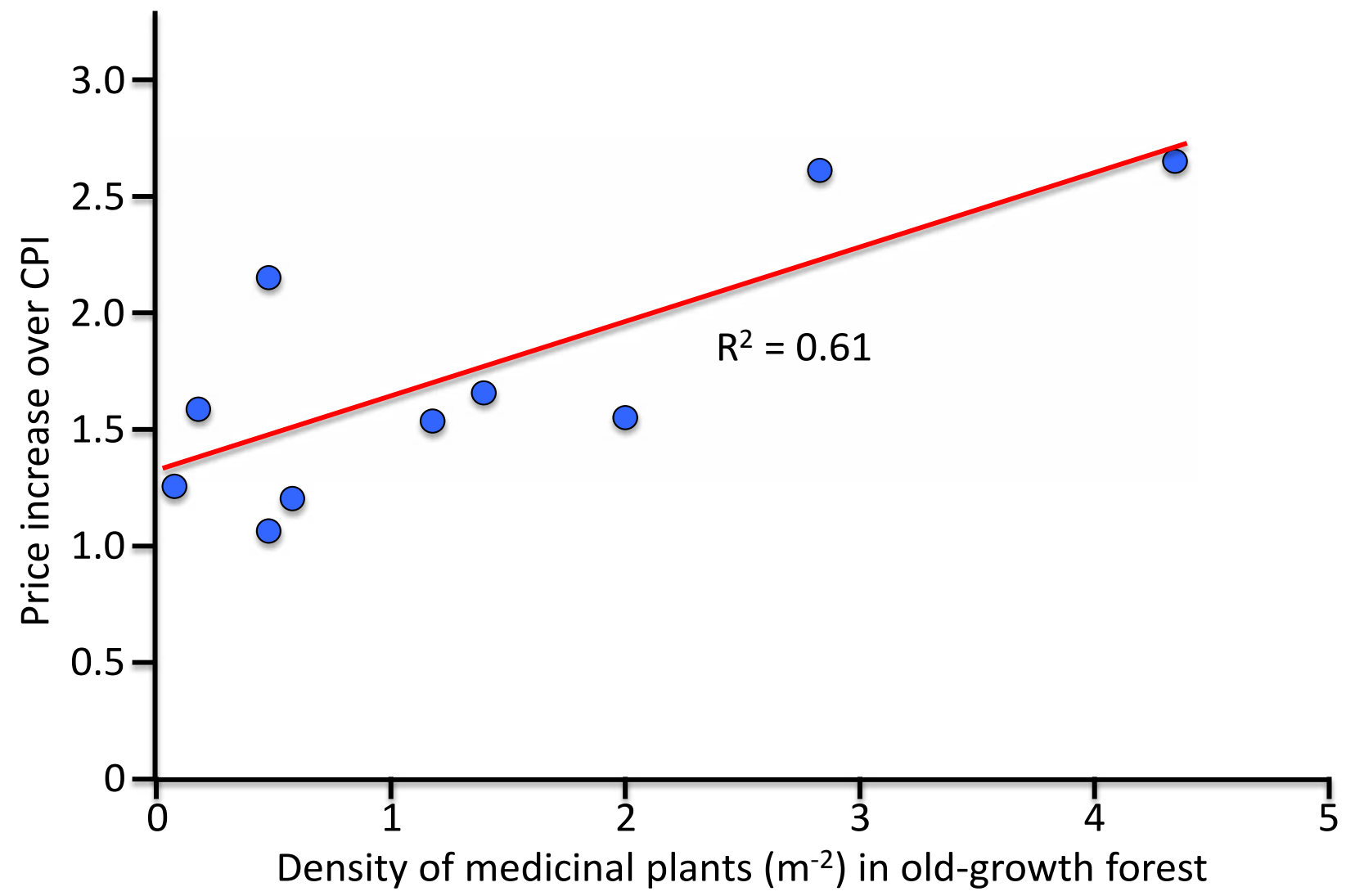

Figure 10. Correlation $(p<0.01)$ between price and density of ten medicinal plant species in old-growth forest in Northwest Pakistan. CPI denotes consumer price index increase between 2006 and 2012.

$\left.\mathrm{m}^{-2}\right)$ but was higher in degraded forest types $\left(1.1 \mathrm{~m}^{-2}, 1.2\right.$ $\left.\mathrm{m}^{-2}, 1.0 \mathrm{~m}^{-2}\right)$ and higher still in the reforestation sites $(2.4$ $\mathrm{m}^{-2}$ ) and re-growth forest $\left(2.3 \mathrm{~m}^{-2}\right)$ (Figure 9F). Bergenia ciliata, $P$. emodi, Sinopodophyllum hexandrum (Royle) T.S.Ying, and $V$. jatamansi were absent from agroforest and degraded forests (Figure 9A, 9D, 9G, and 9I). Densities of the ten medicinal plant species in old-growth forest showed significant correlation $\left(r^{2}=0.61, p<0.01\right)$ with their respective price increase over $\mathrm{CPI}$ values (Figure 10).

\section{Discussion}

Medicinal plants have a variety of other uses such as vegetables, animal fodder, and ethnoveterinary use for the local communities living around Ayubia National Park. The studied medicinal plants are very important for treating various common diseases. For example, V. canescens is locally used for treating chest-related diseases. Such plants are either taken alone or in combination with other plants for making various herbal recipes. Local people living in the mountainous area use their knowledge to treat various diseases (Ahmad \& Javed 2007), and they generally learn how to prepare raw remedies from herbs through individual tutelage and the study of ancestral prescriptions (Ali \& Qaiser 2009). These remedies are be- ing used regularly and are thought to be effective, cheap, and with fewer side effects compared to allopathic drugs, which are often not available to poorer communities.

Medicinal plants serve as a source of income for many rural people in the Pakistani Himalayas. Over seven years, a several-fold increase has been observed in the prices of the studied medicinal plants such as $P$. emodi, $S$. hexandrum, V. jatamansi, and V. cancescens. Shinwari (2010) describes four major reasons related to the price hike in medicinal plants including rising demand from herbal and pharmaceutical industries, increasing medicinal and NTFPs uses, rising use at the local level, and decreasing abundance. However, an average inflation rate of over $13 \%$ (GoP 2013) may also be a significant reason behind the tremendous increase in prices of medicinal plants over the last seven years. Such trends are putting enormous pressure on the abundance of medicinal plants and represent a threat to their existence. In addition, structural changes in the native old-growth forests have also altered the abundance and diversity of medicinal plants, which has had consequences on rural communities dependent upon them. 
Old-growth forest can play an important role in maintaining the abundance and diversity of understory vegetation. In the Himalayan forests, it has been reported that native undisturbed old-growth forests support a higher diversity of ground flora than highly disturbed sites (Bhuyan et al. 2003, Uniyal et al. 2010). The affinity of understory vegetation to old-growth forests has been attributed to several factors such as the reproductive characteristics of the associated plants and the environmental conditions within the forest type, which may include favorable microclimate conditions (e.g., deeply shaded microsites) that are typically less common or absent from various forms of degraded forest (D'Amato 2009). The old-growth forest studied had undergone little or no human disturbance and supported the highest levels of tree canopy cover and medicinal plant abundance of all the forest-use types studied. A higher density of medicinal plants was therefore found to associate with higher tree canopy cover (Adnan \& Hölscher 2011), including the most economically valuable species such as $S$. hexandrum, $V$. jatamansi, and $V$. canescens, all of which are also adapted to deep-shade conditions (Fern 1997). Shanley and Luz (2003) also associated the natural effect of crown cover to the amount of available light for ground vegetation.

Human disturbance sometimes has long-lasting impacts on associated flora, such as local extinctions of certain species where changes in the forest structure persist over longer periods of time (Vellend et al. 2006). Human disturbance can also directly or indirectly affect certain factors that account for change in the abundance of ground vegetation, such as tree canopy, tree basal area, age, temperature, amount of light reaching the forest floor, water requirement, pollen distribution, commensalism, soil $\mathrm{pH}$, and soil nutrient levels (Pitkänen 2000, Shanley \& Luz 2003). In this study, tree canopy cover and densities of medicinal plants were significantly lower in degraded forests (derived woodland, forest degraded by logging, degraded sites). Some of the most economically valuable species-such as $B$. ciliata, $P$. emodi, $S$. hexandrum, and $V$. jatamansi-were absent from the studied degraded forest-use types while $P$. lanceolata was more abundant. Hence, the occurrence and density of certain understory medicinal plants in the degraded forests may depend on factors such as the response of each species to canopy openness and their ability to invade and persist in disturbed habitats. On the other side, the effect of local harvesting on the abundance of medicinal plants cannot be dermined. Ticktin (2004) has explained the ecological implications of harvesting non-timber forest products at the individual level (rate of growth, survival, and reproduction), populations level (structure and dynamics), the communities level (community structure, composition, interactions), and the ecosystems level (nutrient and organic matter dynamics, energy exchange).

Decision makers, scientists, and the interested public now recognize that there is an urgent need to restore forest ecosystems after decades of anthropogenic degradation. In accordance with our findings, other studies have shown that tree canopy cover can increase with forest restoration, which in turn can enhance the abundance of understory flora (Barbier et al. 2008, Carnevale \& Montagnini 2002). Among the restored forests in our study, the highest levels of tree canopy cover and medicinal plant density were recorded under natural re-growth forest, followed by reforestation, with agroforest showing the lowest levels. This variation may be because of species characteristics and, among others, land-use pertaining to each forest-use type. Previous studies have suggested that forest restoration may be a source of improvement in ground vegetation (Islam et al. 2001). It has even been proposed that forest restoration may have a catalytic effect on the regeneration of natural forest biodiversity (Loumeto \& Huttel 1997, Parrotta 1995). Forest restoration can accelerate forest succession on a previously degraded and deforested site by influencing the light availability, understory microclimate, vegetation structural complexity, and development of humus layers during the early years of tree growth (Carnevale \& Montagnini 2002, Yirdaw 2001). Restoration can improve the situation for the conservation of native biodiversity, although negative effects have also been reported (Kanowski et al. 2005, Lamb et al. 2005).

Differences in the abundance of understory flora among the restored forests may be due to variations in tree canopy cover affecting light availability, protection from disturbances, and proximity to old-growth forests. Lamb et al. (2005) reported variations in biodiversity among different forest restoration types. In this study, re-growth forest has a higher abundance of shade-adapted species, while reforestation shows enhanced abundance of partial shade-adapted species. For example, in our study, densities of species such as $V$. jatamansi, $V$. canescens, and $B$. ciliata were higher in re-growth forest, which supports findings of Adnan and Hölscher (2011, 2012), who found that three decades of natural forest re-growth can enhance the abundance of shade-adapted species. In addition, our study also confirmed that the pattern of medicinal plant abundance under re-growth forest is more similar to that occurring under old-growth forest. Tree cover results in the rapid development of a forest structure that favors restoration of forest herbs by creating understory environmental conditions comparable to a natural forest (Paquette et al. 2006). On the other hand, $P$. emodi and $P$. lanceolata showed higher densities under reforestation sites. An abundant understory of native species can be developed under the canopy of fast growing tree species in a plantation (Loumeto \& Huttel 1997), which indicates that this type of reforestation can be used to catalyze secondary succession in degraded areas. However, this is not the case in every reforestation approach, and it depends on various factors such as choice of species, history of the past land use, and plantation method (Kanowski et al. 2005, Larjavaara 2008). Geranium wallichianum 


\section{Adnan \& Hölscher - Medicinal Plants and Forest Transformations in Northwest Pakistan: A preliminary synthesis}

was observed with equal densities between the re-growth and reforestation site in this study.

Agroforest has been observed with lowest abundance of medicinal plants among the restored forests. This may due to low canopy cover coupled with high anthropogenic activities including agricultural practices. Franklin et al. (2000) suggested that heavy plowing equipment used in agroforestry may have profoundly altered some important features of the forest stand's biological legacy, which is supported by Hartley (2002), who reported negative effects of ploughing and scarring on biodiversity. However, in our study, the most valuable medicinal plant species, V. canescens, was observed in higher abundance under agroforest than in degraded forests. Tree canopy cover may have played a role here in increasing the abundance of such valuable species. Many medicinal plants are grown under forest cover and are shade-adapted, and agroforestry offers a convenient strategy for promoting their cultivation and conservation (Rao et al. 2004).

Our results indicate that the densities of ten medicinal plants in old-growth forest are strongly related to their associated increased prices over the consumer price index. Price increases may also pose a threat in terms of increased extraction of medicinal plants from old-growth forests. This supports our hypothesis that forest degradation may lead to a shortage in the availability of medicinal plants. Moreover, our study also suggests that natural re-growth conditions are more effective for the recovery of medicinal plants, probably due to the similarity of this forest-use type to old-growth forest.

\section{Conclusions}

In conclusion, medicinal plants are highly valuable to local people. Increases in the prices of medicinal plants may threaten the studied forest-use types of overexploitation. Higher densities of plants mostly restricted to old-growth forest are highly associated with increases in their market prices. However, this underlying relationship remained unknown and can be explored in the future studies. Oldgrowth forest can sustain the abundance of medicinal plants while degraded forests host lower abundances of medicinal plants, and forest restoration can pave a way toward medicinal plant recovery. Thus, old-growth forest can serve as a diversity bank for understory medicinal plants. This also draws attention to the need for the protection of such forests, which can be achieved by increasing the number and areas of national parks. As forest restoration has positive implications on medicinal plant abundance, this will help in maintaining the diversity of medicinal plants at a regional level and contribute to international conservation initiatives. Management practices in degraded forests can also increase the abundance of species such as $P$. lanceolata that are adapted more to open canopy conditions. Although differences in cur- rent-season harvest between forest-use types cannot be ruled out, they could have driven some observed trends in biomass. Hence, monitoring actual yields in the degraded forests would provide accurate comparative analysis among different forest-use types for proper management.

Our study suggests that re-growth forest is highly beneficial for the herb layer flora, and particularly more shadeadapted species. Moreover, this forest-use type can follow the natural succession process because of its close similarity to old-growth forest in medicinal plant abundance. Hence, shade-adapted, commercially valuable medicinal plants can recover strongly under natural forest re-growth conditions, which could represent an opportunity for ecological restoration. Reforestation has the capability to improve the abundance of medicinal plants, and it can enhance ecological restoration, albeit not as effectively as re-growth. Hence, degraded lands in similar areas have the potential to be reforested, which may provide general support for forest expansion in the region. This will not only meet the increasing demand for timber and wood fuel in the region, but it will stimulate supply in marketable shade-adapted ground flora. Agroforestry may therefore be a viable alternative in the study region, albeit with relatively low abundances of more valuable medicinal plants such as V. canescens compared to other restored forest types. Hence, proper management of reforestation and agroforestry might increase the recovery and abundance of medicinal plants important to rural livelihoods. Lastly, it is recommended to investigate the seven forest-use types for total diversity and abundance of plant species in order to draw concrete conclusions of whether forest restoration categories could serve as successful models on a wider scale. Moreover, a detailed ethno-ecological survey may provide insight on the extent to which local people play a role in forest transformation and subsequent changes in the abundance of medicinal plants.

\section{Acknowledgments}

This work was supported by the Kohat University of Science and Technology (KUST) under the higher education commission of Pakistan's (HEC) Human Resource Development program (HRD) by providing a grant to Muhammad Adnan. The authors are very thankful to the authorities of KUST and HEC for providing this financial support. The authors are also thankful to the World Wide Fund for Nature Pakistan (Peshawar region) team for their kind assistance during data collection.

\section{Literature Cited}

Adnan, M. \& D. Hölscher. 2010. Medicinal plant abundance in degraded and reforested sites in Northwest Pakistan. Mountain Research and Development 30(1):25-32. dx.doi.org/10.1659/MRD-JOURNAL-D-09-00017.1 
Adnan, M. \& D. Hölscher. 2011. Medicinal plants in oldgrowth, degraded and re-growth forests of NW Pakistan. Forest Ecology and Management 261(11):2105-2114. dx.doi.org/10.1016/i.foreco.2011.03.004

Adnan, M. \& D. Hölscher. 2012. Diversity of medicinal plants among different forest-use types of the Pakistani Himalaya. Economic Botany 66(4):344-356. dx.doi. org/10.1007/s12231-012-9213-4

Ahmad, H. 2003. Capacity building for cultivation and sustainable harvesting of medicinal and aromatic plants. Pp. 31-36 in Conservation and Sustainable Uses of Medical and Aromatic Plants of Pakistan. Edited by $\mathrm{H}$. Ahmad \& A.A. Khan. Ethnobotany Project, World Wide Fund forNature Pakistan (WWF-P), Islamabad, Pakistan.

Ahmad, S.S. \& S. Javed. 2007. Exploring the economic value of underutilized plant species in Ayubia National Park. Pakistan Journal of Botany 39(5):1435-1442.

Ali, H. \& M. Qaiser. 2009. The ethnobotany of Chitral valley, Pakistan with particular reference to medicinal plants. Pakistan Journal of Botany 41(4):2009-2041.

Arnold, J.E.M. \& M.R. Pérez. 2001. Can non-timber forest products match tropical forest conservation and development objectives? Ecological Economy 39(3):437-447. dx.doi.org/10.1016/S0921-8009(01)00236-1

Barbier, S., F. Gosselin \& P. Balandier. 2008. Influence of tree species on understory vegetation diversity and mechanisms involved-A critical review for temperate and boreal forests. Forest Ecology and Management 254(1):115. dx.doi.org/10.1016/i.foreco.2007.09.038

Bhuyan, P., M.L. Khan \& R.S. Tripathi. 2003. Tree diversity and population structure in undisturbed and human-impacted stands of tropical wet evergreen forest in Arunachal Pradesh, Eastern Himalayas, India. Biodiversity and Conservation 12(8):1753-1773. dx.doi. org/10.1023/A:1023619017786

Carnevale, N.J. \& F. Montagnini. 2002. Facilitating regeneration of secondary forests with the use of mixed and pure plantations of indigenous tree species. Forest Ecology and Management 163(1-3):217-227. dx.doi. org/10.1016/S0378-1127(01)00581-3

Chao, A., R.L. Chazdon, R.K. Colwell \& T.-J. Shen. 2005. A new statistical approach for assessing similarity of species composition with incidence and abundance data. Ecology Letters 8(2):148-159. dx.doi.org/10.1111/j.1461$\underline{0248.2004 .00707 . x}$

D'Amato, A.W., D.A. Orwig \& D.R. Foster. 2009. Understory vegetation in old-growth and second-growth Tsuga canadensis forests in western Massachusetts. For- est Ecology and Management 257(3):1043-1052. dx.doi. org/10.1016/j.foreco.2008.11.003

FAO (Food and Agriculture Organization). 2010. Global Forest Resources Assessment. FAO Forestry Paper 163. Food and Agriculture Organization of the United Nations, Rome, Italy. www.fao.org/docrep/013/i1757e/i1757e.pdf. Accessed 21 October 2013.

Fern, K. 1997. Plants for Future: Edible \& useful plants for healthier world. Permanent Publications, Hampshire, U.K.

Franklin, J.F., D. Lindenmayer, J.A. MacMahon, A. McKee, J. Magnuson, D.A. Perry, R. Waide \& D. Foster. 2000. Threads of continuity: Ecosystem disturbance, recovery, and the theory of biological legacies. Conservation Spring 2000:8-17.

Ghimire, S.K., D. Mckey \& Y. Aumeeruddy-Thomas. 2004. Heterogeneity in ethnoecological knowledge and management of medicinal plants in Himalayas of Nepal: Implications for conservation. Ecology and Society 9(3):6.

GoP (Government of Pakistan). 2013. Inflation. Pp. 9199 in Pakistan Economic Survey 2012-13. Ministry of Finance, Islamabad, Pakistan. www.finance.gov.pk/survey/ chapters 13/07-Inflation.pdf. Accessed 03 August 2013.

Hamilton, A.C. 2004. Medicinal plants, conservation and livelihoods. Biodiversity and Conservation 13(8):14771517. dx.doi.org/10.1023/B:BIOC.0000021333.23413.42

Hartley, M.J. 2002. Rationale and methods for conserving biodiversity in plantation forests. Forest Ecology and Management 155(1-3):81-95. dx.doi.org/10.1016/S0378$\underline{1127(01) 00549-7}$

Index Kewensis. 1997. Index Kewensis Version 2.0. Oxford University Press, Oxford, U.K.

INRA (French National Institute for Agricultural Research). 2007. Can Eye Software. www.avignon.inra.fr/can eye Accessed 20 October 2009.

Islam, K.R., M.R. Ahmed, M.K. Bhuiyan \& A. Badruddin. 2001. Deforestation effects on vegetative regeneration and soil quality in tropical semi-evergreen degraded and protected forests of Bangladesh. Land Degradation \& Development 12(1):45-56. dx.doi.org/10.1002/ldr.418

ITC (Faculty of Geo-Information Science and Earth Observation). 2007. Integrated Land and Water Information System. www.itc.nl/ilwis Accessed 10 October 2007.

Kanowski, J., C.P. Catterall \& G.W. Wardell-Johnson. 2005. Consequences of broadscale timber plantations for biodiversity in cleared rainforest landscapes of tropical and subtropical Australia. Forest Ecology and Man- 


\section{Adnan \& Hölscher - Medicinal Plants and Forest Transformations in Northwest Pakistan: A preliminary synthesis}

agement 208(1-3):359-372. dx.doi.org/10.1016/j.foreco.2005.01.018

Lamb, D., P.D. Erskine \& J.A. Parrotta. 2005. Restoration of degraded tropical forest landscapes. Science 310(5754):1628-1632. dx.doi.org/10.1126/science. 1111773

Larjavaara, M. 2008. A review on benefits and disadvantages of tree diversity. The Open Forest Science Journal 1:24-26. dx.doi.org/10.2174/1874398600801010024

Loumeto, J.J. \& C. Huttel. 1997. Understory vegetation in fast-growing tree plantations on savannah soils in Congo. Forest Ecology and Management 99(1-2):65-81. dx.doi. org/10.1016/S0378-1127(97)00195-3

Magurran, A.E. 2004. Measuring Biological Diversity. Blackwell Science, Oxford, U.K.

Pitkänen, S. 2000. Effect of tree stand and site variables on alpha diversity of ground vegetation in the forests of northern Karelia. Journal of Environment Management 58(4):289-295.

Parrotta, J.A. 1995. Influence of overstory composition on understory colonization by native species in plantations on a degraded tropical site. Journal of Vegetation Science 6(5):627-636. www.jstor.org/stable/3236433

Parrotta, J.A., J.W. Turnbull \& N. Jones. 1997. Catalyzing native forest regeneration on degraded tropical lands. Forest Ecology and Management 99(1-2):1-7. dx.doi. org/10.1016/S0378-1127(97)00190-4

Paquette, A., A. Bouchard \& A. Cogliastro. 2006. Survival and growth of under-planted trees: A meta-analysis across four biomes. Ecological Applications 16(4):15751589. dx.doi.org/10.1890/1051-0761(2006)016[1575:SA GOUT]2.0.CO;2

Putz, F.E. \& K.H. Redford. 2010. The importance of defining 'Forest': Tropical forest degradation, deforestation, long-term phase shifts, and future transitions. Biotropica 42(1):10-20. dx.doi.org/10.1111/j.17447429.2009.00567.x

Rao, M.R., M.C. Palada \& B.N. Becker. 2004. Medicinal and aromatic plants in agroforestry systems. Agroforestry Systems 61-62(1-3):107-122. dx.doi.org/10.1023/ B:AGFO.0000028993.83007.4b
Robinson, M.M. \& X. Zhang. 2011. The World Medicines Situation 2011. Traditional Medicines: Global situation, issues and challenges. WHO Press, World Health Organization. Geneva, Switzerland. http://digicollection.org/hss/ documents/s18063en/s18063en.pdf. Accessed 04 June 2013.

Shafiq, C.M. 2003. Some Aspects of Bio-ecology of Ayubia National Park Northwest Frontier Province, Pakistan. M.S. thesis, Department of Zoology, University of Karachi, Karachi, Pakistan.

Shanley, P. \& L. Luz. 2003. The impacts of forest degradation on medicinal plant use and implications for health care in eastern Amazonia. Bioscience 53(6):573-584. dx.doi.org/10.1641/0006-3568(2003)053[0573:TIOFDO]2 $0 . \mathrm{CO} ; 2$

Shinwari, Z.K. 2010. Medicinal plants research in Pakistan. Journal of Medicinal Plants Research 4(3):161-176.

SPSS Inc. 2007. SPSS Version 16.0 for Windows. SPSS, Chicago, Illinois, U.S.A.

Ticktin, T. 2004. The ecological implications of harvesting non-timber forest products. Journal of Applied Ecology 41(1):11-21. dx.doi.org/10.1111/j.13652664.2004.00859.x

Uniyal, P., P. Pokhriyal, S. Dasgupta, D. Bhatt \& N.P. Todaria. 2010. Plant diversity in two forest types along the disturbance gradient in Dewalgarh Watershed, Garhwal Himalaya. Current Science 98(7):938-943.

Vellend, M., K. Verheyen, H. Jacquemyn, A. Kolb, H. Van Calster, G. Peterken \& M. Hermy. 2006. Extinction debt of forest plants persists for more than a century following habitat fragmentation. Ecology 87(3):542-548. www.jstor. org/stable/20068974

WWF-P (World Wide Fund for Nature - Pakistan). 2004. People and Plants - Pakistan: Capacity building in ethnobotany applied to conservation and sustainable use of plant resources. Annual Progress Report 1999-2004. WWF-P Peshawar office, Peshawar, Pakistan.

Yirdaw, E. 2001. Diversity of naturally regenerated native woody species in forest plantations in the Ethiopian highlands. New Forests 22(3):159-177. dx.doi. org/10.1023/A:1015629327039 
